\title{
Water Quality Evaluation of Post-Tin Mining Ponds Tourism in Bangka Island Using Diatom as Bioindicator
}

\author{
Rosa Liliani*, Catur Retnaningdyah, Endang Arisoesilaningsih
}

Department of Biology, Faculty of Mathematics and Natural Sciences, University of Brawijaya, Malang, Indonesia

\begin{abstract}
Post tin mining pond in Bangka Island has been used as a tourism place, fishing, fish ponds, and agricultural areas that can reduce water. The purpose of this study is to evaluate the quality of water in the post-tin mining pond which is used as a tourist place based on physics, chemical and biotic indices of Diatoms as bioindicator. Sample water and Diatoms were taken at three post-tin mining pond (Itam, Pedindang, and Jangkang 2) and natural swamp as the reference site. Sampling in each pond and swamp was done in three stations as replications and then physicschemical quality of water were observed $(\mathrm{pH}$, water temperature, turbidity, conductivity, COD, and phosphate) and also the Trophic Diatom Index (TDI) and Pollution Tolerant Value (\% PTV) from Diatom as indicator of trophic status and organic pollution. The results of the study showed that all of the ponds and natural swamp had low pH range from 4.326.34. The turbidity of Itam and Pedindang are higher (22-24 NTU) than Jangkang 2 and swamp (3.13-9.13 NTU). Jangkang 2 had the highest conductivity value $\left(115.10 \mu \mathrm{S} . \mathrm{cm}^{-1}\right)$ and swamp has the lowest $\left(10.64 \mu \mathrm{S} . \mathrm{cm}^{-1}\right)$. The value of COD and total phosphate in all location still meet the government standard (COD $<20 \mathrm{mg} \cdot \mathrm{L}^{-1}$ and total phosphate $<0.2$ mg. $\left.\mathrm{L}^{-1}\right)$. Water quality in post-tin mining ponds is lower than natural swamps based on Diatom as bioindicator. All of the ponds were categorized as moderately polluted based on Shannon Wiener Diversity index of Diatom $(H=1.2-1.6)$, however, the swamp is lightly polluted $(\mathrm{H}=2.6)$. Trophic status of water in post-tin mining ponds based on Trophic Diatom Index (TDI) included in the eutrophic while in swamp categorized as mesotrophic. Based on percentage pollution tolerant value (\%PTV), the water in Itam and Pedindang included in heavily organic pollution and water in Jangkang 2 and swamp have moderate organic pollution.
\end{abstract}

Keywords: Bangka, Diatom, post-tin mining pond, tourism, water quality.

\section{INTRODUCTION}

Bangka Belitung is one of the provinces with abundant mineral resources, namely tin and is widely distributed on the sea floor or land [1]. Tin mining in Bangka Belitung has existed for long time and more than 200 years ago [2]. The Center for Geological Resources in 2007 are 4.037.304 tons of seed and form 622.626 tons of metals.

Tin mining activities will definitely have a positive or negative impact on the environment. Tin mining has an influence on Regional Original Income (PAD) as well as improving community economics [3]. The negative impact of tin mining activities is the disruption of natural ecosystems included plant vegetation and soil. Post-tin mining pond will be filled with water to form a pond. Human activity around post-tin mining pond still continues today. The surrounding community is still using post-tin mining pond for daily needs such as bathing, washing, and as a tourist place.

\footnotetext{
${ }^{*}$ Correspondence address:

Rosa Liliani

Email : rosaliliani.rl@gmail.com

Address : Dept of Biology, University of Brawijaya, Veteran Malang, Malang 65145
}

Post-tin mining ponds are seen as economically potential and have benefits as raw water sources, aquaculture and recreational areas that are managed directly by tin companies or by the government. Utilization of various tin mining pond in Bangka Island is various, such as fishing grounds, ornamental fish ponds, and recreational water playgrounds.

Post-tin mining pond in Bangka Island is currently being utilized by the government and assisted by the community as a water recreation and fishing place. Around the pond was made like a bridge and colorful, and added several boats to attract visitors.

If the tourism sector can be managed properly, it can improve the economy of the community by utilizing the potential of the surrounding nature and culture. Tourism development of post-tin mining pond can be done by changing the inheritance of tin mining activities into local tourism resources [4].

Water quality is one of the important factors to determine changes and levels of environmental pollution due to human activities. One way to find out the condition of water in post tin mining pond is to be seen from the physics factors of water chemistry and biology, namely from the composition and structure of 
Diatoms as a bioindicator of changes in environmental quality [5].

Based on the above, the objective of this research was evaluating the water quality of post tin mining pond which was used as a tourist spot. Water quality is determined based on the physics chemical parameters of water and some biotic indices of Trophic Diatom Index (TDI) and Pollution Tolerant Value (\%PTV) as bioindicator.

\section{RESEARCH METHODS}

\section{Study area}

The research was conducted from AprilSeptember 2018 in three post-tin mining pond (Itam, Pedindang, and Jangkang 2) in Bangka and one swamp as a reference site (Fig. 2). Water and diatom samples were taken in the morning until noon. Abiotic and Diatom factors were identified and analyzed in the Laboratory of Ecology and Animal Diversity, Department of Biology, Faculty of Mathematics and Natural Sciences, University of Brawijaya Malang.

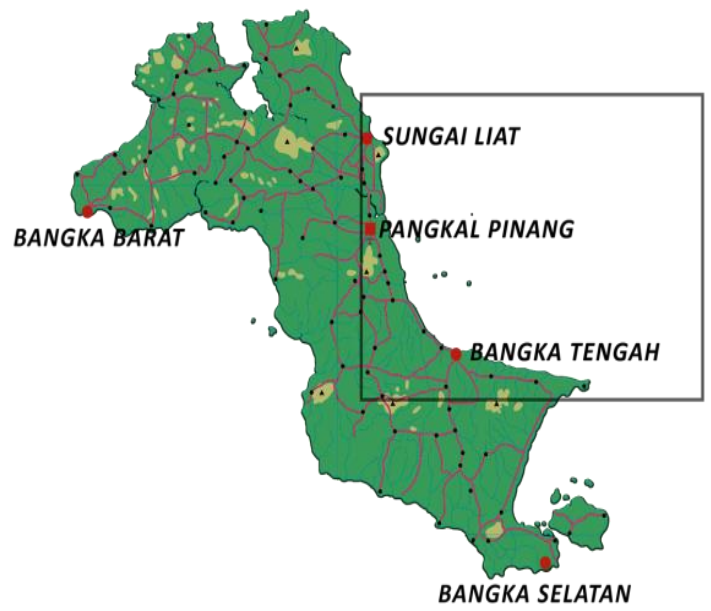

Figure 1. Map of Bangka Island

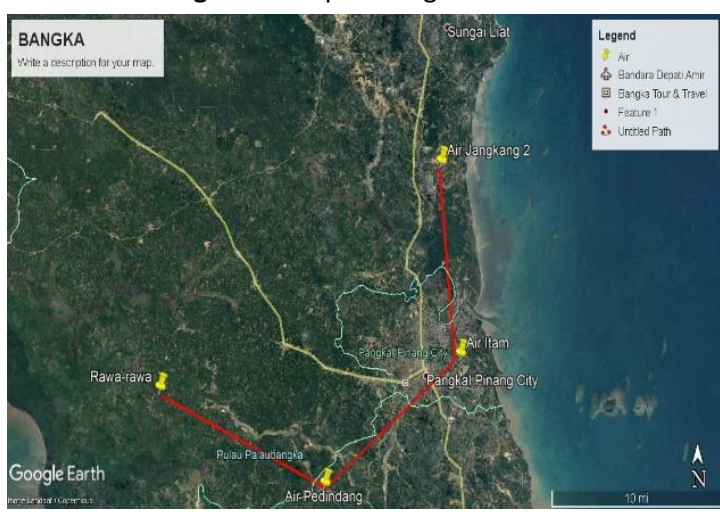

Figure 2. Sampling Locations of in Bangka

\section{Water Physics and Chemical Quality}

The physics and chemical parameters of water were measured, i.e. the water temperature measured by a digital thermometer, turbidity with turbidity meters, conductivity with conductivity meters, $\mathrm{pH}$ with $\mathrm{pH}$ meters, along with COD and Total Phosphate. Based on the standard method of the Official and Analytical Chemical Association all parameters are measured in triplicate [6].

\section{Diatom Sampling}

Diatom samples at each study location were determined at the same location as the physics and chemical sampling location by taking a 1 Liter water sample using a vertical water sampler at a water depth of 3-5 meters and then water filtered using plankton net. Diatom samples were preserved using 10 drops of $4 \%$ formalin and 5 drops of $\mathrm{CuSO}_{4}$. Water and diatom samples in each location were taken at three stations so that a total sample is 12 samples.

\section{Data analysis}

Physics and chemical quality data for each location were compiled and analyzed by different tests between research stations using ANOVA followed by Turkey HSD (if data distributions normal) and Brown-Forsythe test and continued with Gamess-Howell test (if data distributions are not homogenous). The results of identification and count the density of each Diatom species used for determinate Taxa Richness, ShannonWiener Diversity Index $(\mathrm{H})$, Trophic Diatom Index (TDI), and percentage Pollution Tolerant Value (\% PTV) which is indicated organic pollution in water [7,8]. Diatom was identified using morphological characters with reference $[9,10,11]$.

\section{RESULT AND DISCUSSION \\ Water Quality of Post-Tin Mining Pond at Bangka Island Based on Physical-Chemical Parameters}

Parameters of physics and chemistry can be used as indicators of the water quality so that it can greatly affect the aquatic biota in these waters, one of which is Diatom. Results of analysis of measurements of water and physics meters in three post-tin mining ponds in Bangka Island and one swamp in the form of a reference site can be seen in Table 1.

The result of water monitoring indicated that the acidity $(\mathrm{pH})$ of water post tin mining pond in the range of $5.49-6.34$. The highest $\mathrm{pH}$ value was found in Itam, while the lowest $\mathrm{pH}$ value was in Jangkang 2. The results of $\mathrm{pH}$ measurements post-tin mining pond in Bangka Island have a range value that wasn't significant. Aquatic organisms in water can live with a $\mathrm{pH}$ value 
ranging from $6.6-8.5$ namely tolerance between weak acids to weak bases. Water with very acidic or very alkaline conditions can endanger the survival of an organism, such as Diatom [12]. Acidity $(\mathrm{pH})$ is one of the environmental parameters that control the survival of Diatoms and the process of extracting nutrients, the balance of minerals and the balance of metals found around the pond $[13,14]$.

The results of temperature measurements in the water of post-tin mining pond in Bangka Island show that the water temperature ranges from $29.8-32.6^{\circ} \mathrm{C}$ (Table 1 ). The highest water temperature was found in the Itam location and the lowest water temperature was in the swamp. This can be influenced by the intensity of sunlight, the activity of heat exchange between water and around the pond, and also the condition of vegetation around post-tin mining pond. Lower temperatures can originate from turbulence caused by movements of water that make water lose heat [15].

Turbidity can describe the optical properties of water, determined based on the amount of light absorbed and emitted by the ingredients contained in water. Turbidity can be caused by the presence of organic or inorganic materials suspended and dissolved in water [16]. Based on Table 1, the value of turbidity post-tin mining pond in Bangka Island ranges from $3.13-23.63$
NTU. The optimum turbidity value of a water range between 5-30 NTU. The highest turbidity value was located in the location of Itam while the lowest was located in the swamp. The high value of turbidity in Itam can be caused by heavy metals inside the post-tin mining pond and inorganic or organic material suspended or dissolved in water [17].

The conductivity value post-tin mining pond in Bangka Island ranges from 10.64 - 115.10 $\mu \mathrm{S} . \mathrm{cm}^{-1}$. Jangkang 2 has the highest conductivity value, while swamp has a low conductivity value (Table 1).

COD value (oxygen content needed to degrade chemically organic matter) of water in post-tin mining pond of Bangka Island ranges from 9.13 - $18.23 \mathrm{mg} \cdot \mathrm{L}^{-1}$. Pedindang has the highest COD value while Itam has the lowest COD value. According to UNESCO/WHO/UNEP in 1992 the quality standard or COD value is less than 20 $\mathrm{mg} \cdot \mathrm{L}^{-1}$. It can be said that the water is not contaminated [18].

The result of measurements in Table 1, it show that the total phosphate value post-tin mining pond in Bangka Island ranges from $<0.03$ $-0.09 \mathrm{mg} \cdot \mathrm{L}^{-1}$. The analysis total phosphate results based on the quality standard of $0.2 \mathrm{mg} \cdot \mathrm{L}^{-1}$ according PP 82 of 2001 Class II Province of Bangka Belitung Islands. The highest total phosphate is located in Pedindang.

Table 1. Physical and Chemical Parameters of Water in the Post-tin Mining Pond in Bangka Island

\begin{tabular}{|c|c|c|c|c|c|c|}
\hline Location & $\mathrm{pH}$ & $\begin{array}{c}\text { Water } \\
\text { temperature }\left({ }^{\circ} \mathrm{C}\right)\end{array}$ & $\begin{array}{l}\text { Turbidity } \\
\text { (NTU) }\end{array}$ & $\begin{array}{c}\text { Conductivity } \\
\left(\mu \mathrm{S} . \mathrm{cm}^{-1}\right)\end{array}$ & $\begin{array}{c}\text { COD } \\
\left(\mathrm{mg} \cdot \mathrm{L}^{-1}\right)\end{array}$ & $\begin{array}{c}\text { Total Phosphate } \\
\left(\mathrm{mg} \cdot \mathrm{L}^{-1}\right)\end{array}$ \\
\hline Itam & $6.34 \pm 0.16$ & $32.60 \pm 1.40$ & $23.63 \pm 5.60$ & $65.97 \pm 3.37$ & $9.13 \pm 0.45$ & $<0.03-0.04$ \\
\hline Pedindang & $6.22 \pm 0.52$ & $31.10 \pm 0.10$ & $22.20 \pm 8.32$ & $93.23 \pm 1.22$ & $18.23 \pm 3.52$ & $0.09 \pm 0.02$ \\
\hline Jangkang 2 & $4.32 \pm 0.08$ & $32.20 \pm 0.10$ & $9.13 \pm 2.55$ & $115.10 \pm 2.16$ & $8.98 \pm 0.21$ & $<0.03$ \\
\hline Swamp (rawa) & $5.49 \pm 0.28$ & $29.80 \pm 1.40$ & $3.13 \pm 2.47$ & $10.64 \pm 3.22$ & $9.42 \pm 0.49$ & $<0.03-0.13$ \\
\hline $\begin{array}{l}\text { *Government } \\
\text { standard }\end{array}$ & $6-9$ & - & 5-30 NTU & 25 & & 0.2 \\
\hline
\end{tabular}

Note: * Government Regulation No. 82, 2001

Diatom in Post-tin Mining Pond in Bangka Island

The number of diatom taxa was mostly found at the location of the swamp (Fig. 3). This show that the condition of the location has not been contaminated by heavy metals, where the location is far from the tin mining location. Swamp is a reference site. While the Pedindang is the location with the lowest number of taxa.

Pollution is a condition that has changed from the original (good) to the worse state. Changes from the original conditions under these adverse conditions can occur as inputs from pollutants originated from post-tin mining pond. These pollutants, in general, has toxic properties that are harmful to the survival of the organism [19].

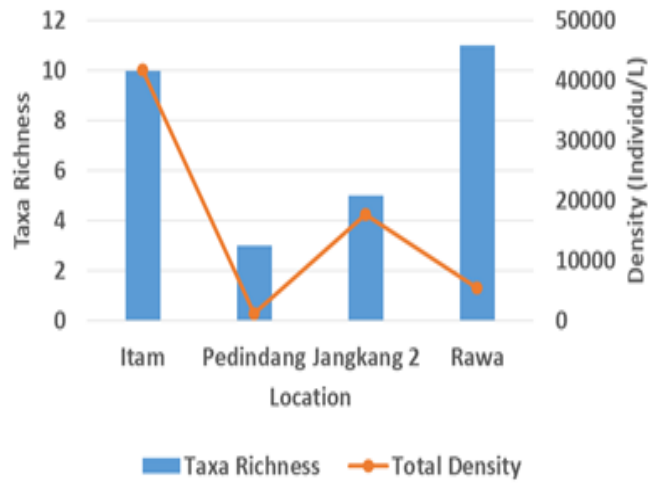

Figure 3. The Taxa Richness and Density of Diatom in Post-tin Mining Pond in Bangka Island 
The calculation of the Shannon-Wiener diversity index $\left(\mathrm{H}^{\prime}\right)$ of Diatom in post-tin mining pond in Bangka Island (Fig.4), showed that swamp are categorized as very good or not polluted with a value of $H^{\prime}=2.6$. The pond of Itam, Pedindang, and Jangkang 2 have low diversity taxa (3-10.5) which are categorized as moderate pollutions. Differences in the value of diversity index can be influenced by the number of species in the community post-tin mining pond in Bangka Island, water depth, availability food in water, and human activities. A community has a high species diversity when many species with relatively even numbers of individuals. If a community consists of only a few species without the number of individuals distributed equally, the community has a low diversity [20].

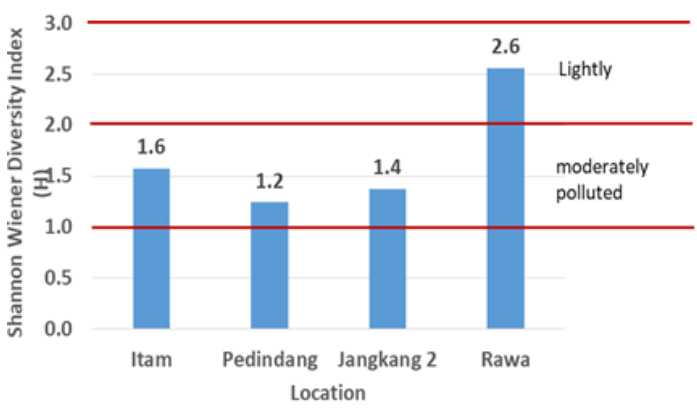

Figure 4. Shannon-Wiener Diversity Index of Diatom in Post-tin mining pond in Bangka Island

Tropical status and the level of pollution of organic matter in water can be assessed by the TDI (Fig. 5) and the Organic Pollution Level (\% PTV) (Fig. 6) which was used to show the level of eutrophication, organic pollution, and toxin pollution levels [21]. Based on the results of the tropical status assessment (Fig. 5) the quality of water in post-tin mining pond Bangka Island is classified as mesotrophic to eutrophic. Jangkang 2 has the highest value of TDI and classified as eutrophic, while the lowest TDI value is swamp belonging to the mesotrophic.

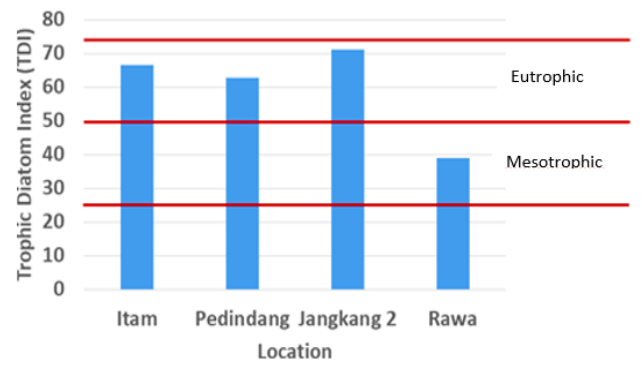

Figure 5. Trophic Status of Water in Post-tin Mining Pond in Bangka Island based on the Trophic Diatom Index (TDI)

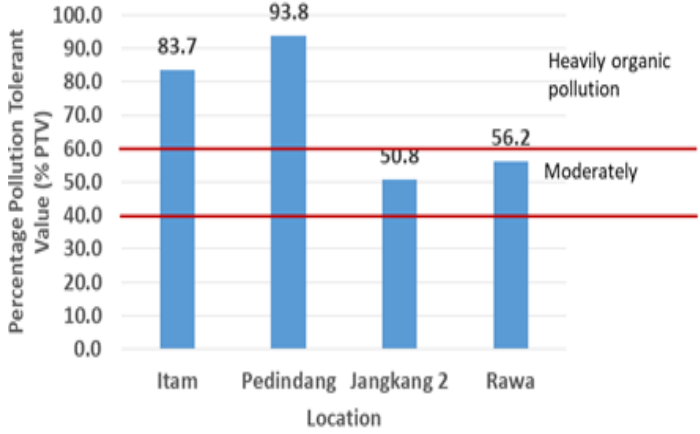

Figure 6. The level of water pollution post tin mining pond in Bangka Island based on Percent Tolerance Value (\% PTV)

Based on the results obtained, the trophic status of the post-tin mining pond in Bangka Island has a significant impact on the quality of water mesotrophic to eutrophic. Diatoms are often used as bioindicators of water quality in water to indicate the condition of the waters from the level of pollution of organic matter [22].

The results of the IVI study report (Fig. 7) in four different research locations showed that each location values have a different species. Nitzschia sp and Navicula sp species are Bacillariophyceae classes that can be found in all locations. This showed that Nitzschia sp and Navicula sp have very good adaptability. The Bacillariophyceae class is phytoplankton that has a tolerance to temperature, nutrition, and sunlight [23]. The Bacillariophyceae class can grow fast even under poor nutritional conditions and low sunlight [24].

Navicula sp and Nitzschia were co-dominate in Pedindang, while Synedra sp and Navicula sp were co-dominate species in Jangkang 2 . This type of Diatom is able to adapt to turbid aquatic environments which are tolerant of waters with high organic matter content [25].

Post-tin mining pond that being used in various activities such as tourist and fishing provide influence on water quality based on physics, chemical and Diatoms as bioindicator. It can be grouped using biplot analysis. The effect of human activities in the post-tin mining pond can be seen from the classification of water quality based on physics-chemical parameters and Diatoms using cluster and biplot analysis. The grouping water quality in post-tin mining ponds and natural swamp can be seen from biplot analysis, based on several physicalchemical parameters of water and biotic index on water quality (Fig. 8).

The quality of post-tin mining pond water in Bangka Island has different characteristics. 


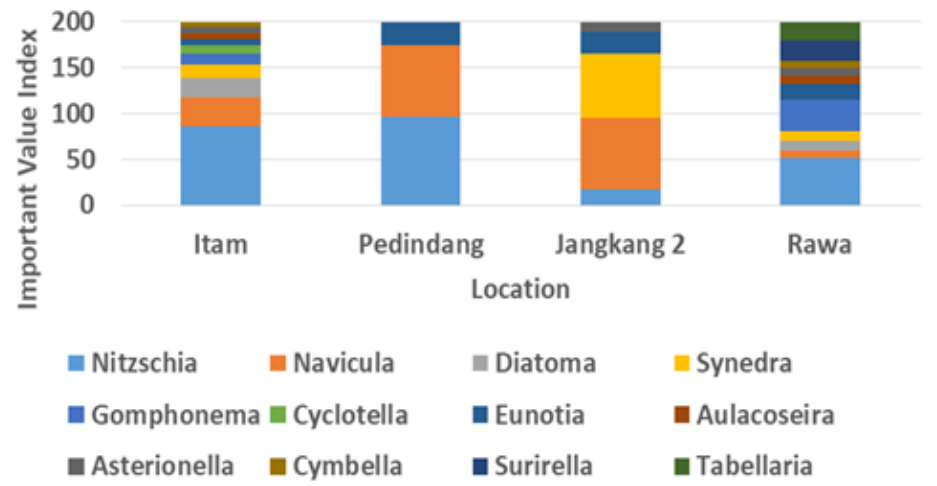

Figure 7. Important Value Index (IVI) of Diatom in post tin mining pond in Bangka Island

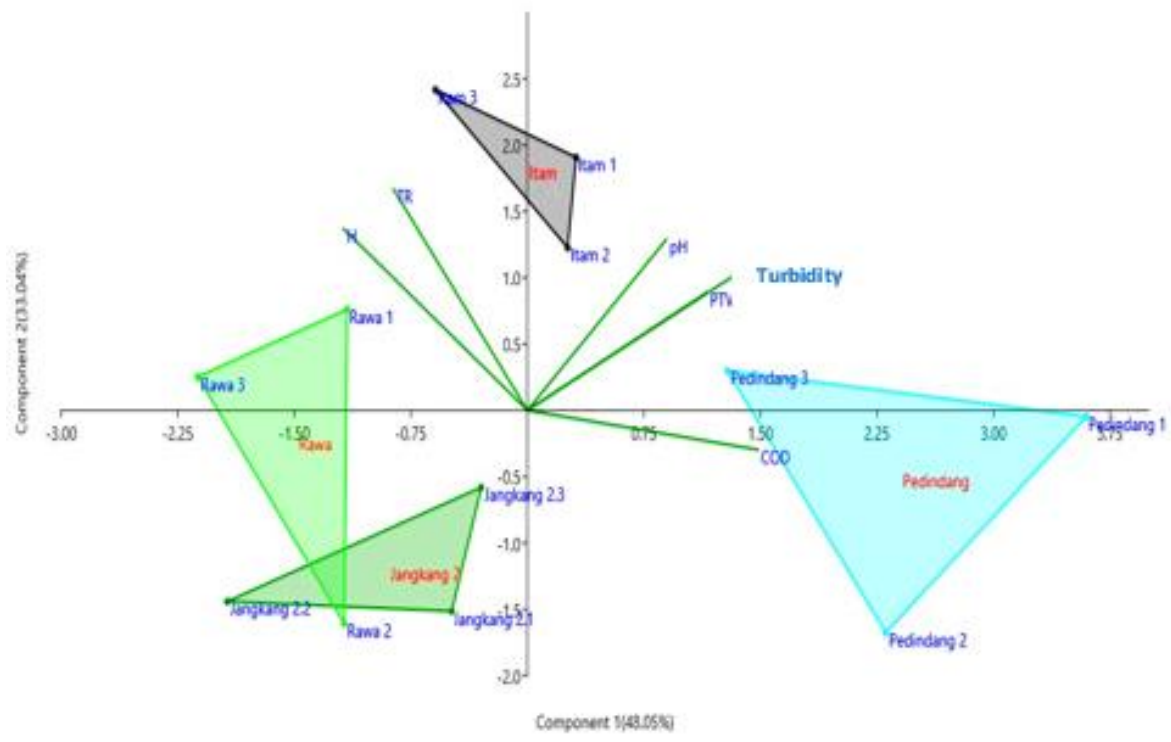

Figure 8. Effect of Tourism Activities on Post-tin Mining Pond in Bangka Island to the Characteristics of Water Quality

Jangkang has almost the same characteristics as Swamp, while Itam has almost the same characteristics as Pedindang. Water quality at Jangkang and swamp locations was characterized by high $\mathrm{H}$ values and taxa richness, while Itam and Pedindang are characterized by high COD, \%PTV, turbidity, and low $\mathrm{H}$.

Water quality in the Pedindang location is characterized by COD, \% PTV and higher turbidity. It shows that the level of pollution of organic matter is high. Meanwhile, Itam is characterized by a higher $\mathrm{pH}$ value. Jangkang 2 has a lower value of COD and \% PTV which shows better trophic status with low levels of organic matter pollution, with good water conditions. It is characterized by high $\mathrm{H}$ values and taxa richness. Swamp is a reference site located far from tin mining activities while Jangkang 2 is a tourist site, but it is one of the post-tin mining ponds that became a reclamation program from PT. Timah Tbk. Otherwise, Itam and Pedindang included as contaminated by heavy organic materials. Tourism activities around the ponds have reduced mesotrophic status to eutrophic, with moderate to severe pollution.

\section{CONCLUSION}

The quality of water in the swamp and several aquatic ecosystems in Bangka Island greatly varies. Based on the calculation of Shannon-Wiener's diversity value, the natural swamp (2.6) is in a good category. The water quality of post-tin mining pond in Bangka Island based on the Diatom biotic index of Trophic Diatom Index showed categories as mesotrophic to eutrophic (39-71). The level of organic pollution in post-tin mining pond is heavy with a value of PTV (50.8-93.8\%), which was moderate to heavy organic water pollution.

\section{Acknowledgement}

Thanks to PT. Timah Tbk in Bangka Island who provided information and allowed the 
researchers to take samples. We also thanks all of colleague and staff of Laboratory of Ecology and Animal Diversity, University of Brawijaya, Malang.

\section{REFERENCES}

[1] Asmarhansyah. 2016. Karakteristik dan strategi pengelolaan lahan bekas tambang timah di Kepulauan Bangka Belitung. Proceeding of National Seminar of Agriculture Technology Innovation. Banjarbaru.

[2] Lembaga Penerbangan dan Antariksa Nasional (LAPAN). 2014. Pemanfaatan data penginderaan jarak jauh untuk identifikasi sumberdaya mineral di Bangka Belitung (studi kasus: timah). Jakarta.

[3] Ibrahim. 2011. Pertimahan dalam perspektif ekonomi Pancasila (studi kasus di Provinsi Kepulauan Bangka Belitung), PhD Thesis. Department of Philosophy. Gadjah Mada University. Yogyakarta.

[4] Ballesteros, E. R. and M. H. Ramírez. 2007. Identity and community-reflections on the development of mining heritage tourism in Southern Spain. Tourism Management 28, 677-687.

[5] Viani, D. Z. and C. Retnaningdyah. 2018. Evaluasi status trofik dan pencemaran bahan organik di Waduk Lahor Malang menggunakan bioindikator diatom. Jurnal Biotropika 6(1), 10-15.

[6] AOAC. 2003. Official methods of analysis Vol. I, $17^{\text {th }}$ ed. Association of Analytical Washington, DC, USA.

[7] Van Dam, H., A. Mertens, J. A. Sinkeldam. 1994. Coded checklist and ecological indicator values of freshwater diatoms from the Netherlands. Netherlands Journal of Aquatic Ecology 28, 117-133.

[8] Kelly, M. and B. Whitton. 1995. The trophic diatom index: a new index for monitoring eutrophication in rivers. Journal of Applied Phycology 7, 433-444.

[9] Davis, C. C. 1955. The marine and freshwater plankton. Michigan State University Press. East Lansing.

[10] Yamaji I. 1966. Illustrations of the marine plankton of Japan. Hoikush. Japan.

[11] Shirota, A. 1966. The plankton of South Vietnam: freshwater and marine plankton. Overseas Technical Cooperation Agency. Japan.

[12] Welch, P.S. 1952. Limnology. Mc. Graw Hill Book Company. New York.
[13] Abel, P.D. 1989. Water pollution biology. John Wiley and Sons. New York.

[14] Connell,D. W. and G. J. Miller. 1995. Kimia dan ekotoksikologi pencemaran. Yanti, R.H. (Trans.). University of Indonesia Press. Jakarta. 222-223.

[15] Abubakar, M. M. and S. M. Yakasai. 2012. A water quality and phytoplankton of Salanta River Kano, Nigeria. Journal of Biological Science and Bioconservation 4, 65-73.

[16] Faza, M. F. 2012. Struktur komunitas plankton di Sungai Pesanggrahan dari bagian hulu (Bogor, Jawa Barat) hingga bagian hilir (Kembang, DKI Jakarta). Universitas Indonesia Press. Jakarta.

[17] Salwiyah. 2010. Kondisi kualitas air sehubungan dengan kesuburan perairan sekitar PLTU Tanasa Kabupaten Konawi Provinsi Sulawesi Tenggara. Jurnal Wiptek 18(2), 52-56.

[18] Effendi, H. 2003. Telaah kualitas air bagi pengelolaan sumber daya lingkungan perairan. Kanisius. Jakarta.

[19] Prianto, E. and Husnah. 2009. Penambangan timah inkonvensional: dampaknya terhadap kerusakkan biodiversitas perairan umum di Pulau Bangka. BAWAL 2(5), 193198

[20] Wirabumi, P. 2017. Plankton community structure in the reservoir Wadaslintang Wonosobo District. Jurnal Prodi Biologi 6(3), 174-184.

[21] Wu, N., B. Schmalz and N. Fohrer. 2014. Study progress in riverine Phytoplankton and its use as bio-indicator - a Review. Austin Journal of Hydrology 1(1), 9.

[22] Retnaningdyah, C. and E. Arisoesilaningsih. 2018. Using benthic diatom to assess the success of batch culture system phytoremediation process of water irrigation. Journal of Tropical Life Science 8(3), 259-268

[23] Nontji, A. 2008. Plankton laut. Indonesian Institute of Sciences. Jakarta.

[24] Faqah, E. 2009. Kelimpahan dan distribusi fitoplankton serta hubungannya dengan kelimpahan dan distribusi zooplankton. University of Indonesia. Depok.

[25] Soeprobowati, T. R. 2010. Stratigrafi diatom Danau Rawa Pening : kajian paleolimnologi sebagai landasan pengelolaan danau. Paper in National Seminar Nasional Limnologi V. Limnology Study, Indonesian Institute of Sciences. Bogor. 